and Civilisation Faults: Environmental and Politological Analysis] (pp.43-56). Sotsialno-Politicheskiy Zhurnal [Socio-Political Journal]. No. 5 [in Russian].

Peirce, Ch.S. (2000). Selected Philosophical Writings. - Moscow.

Prohovnik, O.A. (2006). Kulturno-antropologicheskiy krizis i noviye zadachi obrazovaniya v epohu postsovremennosti [Cultural and Anthropological Crisis and New Objectives of Education in the Era of Post-modernity]. - Rostov-on-Don [in Russian].

Putin, V.V. (2013). Report at Valday Discussion Club. htt://ru - an.info/nevs/2555 [in Russian].

Reimers, N.F. (2000). Ekologiya: teoriya, zakony, pravila, printsipy, gipotezy [Ecology: Theory, Laws, Rules, Principles, Hypothesis]. Moscow: Prosvescheniye (1994) [in Russian].

Rozhkov, M.I. (2000). Organizatsiya vospitatelnogo prostranstva v shkole [Organization of Educational Environment at Schools]: study guide for students of higher educational establishments. -Moscow: Vlados [in Russian].

Sartre, J.P. (1990). Existentialism is Humanism. Dusk of the Gods (pp. 315-345). - Moscow: Politizdat

Shatskiy, S.T. (1980). Izbranniye pedagogicheskiye sochineniya [Selected Pedagogical Writings]. - Moscow: Pedagogika

Soroka-Rosinskiy, V.N. (1996). Vospitaniye kak pedagogicheskoye yavleniye. Obsschiye zakonomernosti i printsipy vospitaniya [Education as Pedagogical Phenomenon. General Laws and Principles of Education] (p.34). Pedagogika [in Russian].

Suprunova, L.L. (2014). Polikulturnoye obrazovaniye v sovremennoy Rossii. Nravstvennost. Kultura. Sovremennost. Eticheskaya Mysl [Multi-cultural Education in Modern Russia/Morality. Culture. Modernity. Ethical Idea] (pp.16-58). - Moscow [in Russian].

Yadov, V.A. (2006). Sovremennaya teoreticheskaya sotsiologiya kak kontseptualnaya baza issledovaniy rossiyskih transformatsiy [Modern Theoretical Sociology as a Conceptual Basis for Research of Russian Transformations]. - St. Petersburg: Intersotsis [in Russian]. 


\title{
Cattle Marketing Social Network among the Rural Native Community, Sarawak, Malaysia: A Qualitative Research
}

\author{
Novel Lyndon ${ }^{1}$ \\ Sivapalan Selvadurai² \\ Rosniza Aznie Che Rose ${ }^{3}$ \\ Hng Siew Hong ${ }^{4}$ \\ ${ }^{1}$ Associate Professor at School of Social Development and Environmental Studies, Faculty of Social Sciences and Humanities \\ Universiti Kebangsaan Malaysia, Bangi, UKM 43600, Selangor D. E., Malaysia, novellyndon@yahoo.com \\ ${ }^{2}$ Associate Professor at School of Social Development and Environmental Studies, Faculty of Social Sciences and Humanities, \\ Universiti Kebangsaan Malaysia, Bangi, UKM 43600, Selangor D. E., Malaysia, sivap02@gmail.com \\ ${ }^{3}$ Senior Lecturers at School of Social Development and Environmental Studies, Faculty of Social Sciences and Humanities, \\ Universiti Kebangsaan Malaysia, Bangi, UKM 43600, Selangor D. E., Malaysia, aznie@ukm.edu.my \\ ${ }^{4}$ Lecturer at Nursing Department, UKM Medical Centre, Jalan Yaacob Latif, Bandar Tun Razak, 56000 Cheras, \\ Wilayah Persekutuan Kuala Lumpur, Malaysia, hng@ppukm.ukm.edu.my
}

Doi:10.5901/mjss.2015.v6n5s1p269

\section{Abstract}

Social network is a very important aspect for the farmers to find the customers, finding a good offer price, finding a wide market and dominates the local market of their products. Therefore, the main objective of this research is to examine the types of social network used by these farmers in finding market. This study was conducted at District of Serian, Sarawak, Malaysia. This research employed abductive research strategy where the types of social network are constructed by the cattle farmers themselves based on their own experience and knowledge after being involved in cattle farming for 10 years. Data were collected using in-depth interviews and non-participant observation. Most of the interviews carried out took between two to three hours; however, some of the interviews took quite a long time. Sample size in this research was determined based on data saturation. Therefore, a total of nine people were chosen as informants in the study using purposive sampling and snowball sampling. Validity and reliability of the research data were determined using member check approach. All the interviews was transcribed and formatted to be entered into the Nvivo database and will be used to create categories and to index the data. Findings of the study showed that seven types of social network were used by the cattle farmers in the rural areas in marketing their livestock, namely through networks of family ties, friends, friends of friends, advertisements, radio, type of language and wholesalers. The seven types of social network are viewed to have helped them in maintaining their status quo as successful cattle farmers.

Keywords: Cattle farmers, marketing, social network, Bidayuh community

\section{Introduction}

At a glance, the rate of Sarawak's economic growth is very high after achieving independence with the average rate of annual growth recorded at 7.9 percent since the 1960s (Abdul Rashid, 1990; Novel, et al. 2011; Ridu, 1994). Between 1970 until 1975, the percentage of its annual economic growth had risen to 7.9 percent and 11.4 percent between 1970 and 1972 (Grijpstra, 1976). However, in 2006 there was a slight decline recorded with the annual economic growth rate of Sarawak reported at 17.5 percent compared to 18.4 percent which was recorded for 2005 (Sarawak, 2007). For the year 2008 , the rate of annual economic growth for Sarawak was expected to increase again to 18.5 percent compared to the 17.8 percent recorded for 2007 (Sarawak, 2008). Subsequently, in 2009, Sarawak's rate of economic growth continued to increase to 19.8 percent and in 2010, its percentage had increased to 20.1 percent (Sarawak, 2010) (please refer to Figure 1 below). 


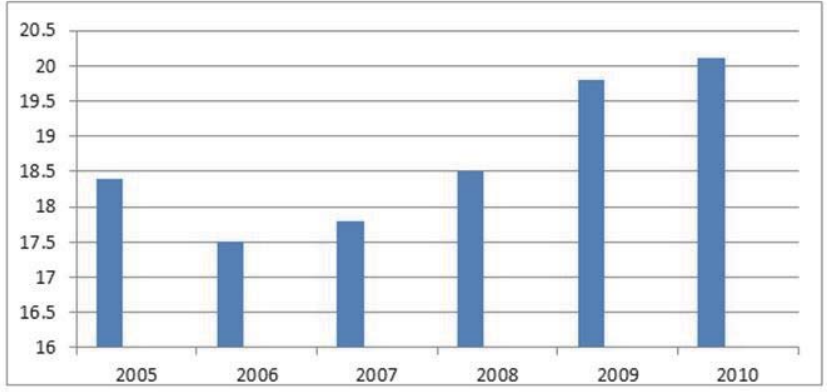

Figure 1: Economic Growth Rate of Sarawak, Malaysia, Year 2005-2010

Source: Sarawak Planning Unit, 2010

\section{Literature Review on Sarawak Economy}

In terms of per capita GDP (Grose Domestic Product), the amount recorded for 2006 was a total of RM26,912 while for 2007, the per capita GDP (current price) recorded was a total of RM29,175. Subsequently, for 2008, the per capita GDP (current price) for Sarawak was expected to increase to RM31, 836 (Malaysia, 2008). In 2010, Sarawak had the third largest state economy in Malaysia after Selangor and Johor with a total nominal GDP of RM 50,804M (USD\$ 16,542M). Sarawak is also the second largest state in terms of GDP per capita after Penang with RM 33,307.00 (USD\$10,845.00) in 2010. In term of revenue, it was reported to increase to RM2.859 billion in 2005 compared to RM2.583 billion for 2004. For the year 2010, Sarawak's government revenue was reported to will have increased to RM5.854 billion compared to RM4.854 billion recorded for 2006 (Sarawak, 2010). Sarawak's economy in general, relies too much on the primary sector production such as mining, logging and main agricultural produce such as rubber, palm oil and black pepper as well as livestock rearing such as cattle and pigs. For example, in 1995, Sarawak's export fraction contribution was 44 percent from petroleum and petroleum products, 22 percent from logging, 4 percent from agricultural produce and 29 percent from other produce (Sarawak, 1995). Meanwhile, in 2010, the petroleum and gas sector continued to be the major contributor to state revenue that was estimated to reach RM935 million or 35 percent of the total overall revenue of the Sarawak state (Sarawak 2010).

The forestry sector is also an important contributor to the state's economy with a contribution totalling RM699 million or 27 percent of the overall total of Sarawak's revenue (Sarawak, 2010). Investment revenue from accumulated dividend yield from equities held by the state in companies was expected to contribute a total of RM4335 million or 13 percent (Sarawak, 2010). Industry does not play a major role in Sarawak because of the low population rate and limited market except for timber for export. Although gas and petroleum form more than 60 percent of the state's foreign revenue power, only 5 percent of the product's segment is distributed to the state's finance and this situation indirectly has made the logging sector and major agricultural product sector such as oil palm the main contributor to the economic source of Sarawak (Sarawak, 2010). Departing from this point, Sarawak's economy in the future is seen more risky, fragile and in an unstable position because its main economic activities rely heavily on non-renewable economic sources (Novel, et al. 2013).

This situation is even gloomier when there is deficiency of economic source diversity. Even though the size of Sarawak state is large, its population density is found to be the least compared to other states in Malaysia with a total population rate recorded in 2005 estimated at 2.31 percent only, of which 70 percent consists of Bumiputera ethnics and 30 percent Chinese ethnics (Madeline, 2004). Sarawak has the most number of diverse indigenous groups in Malaysia, namely 23 ethnic groups and 10 ethnic sub-groups (Madeline, 2004). A total of 30 percent of the Bumiputera ethnic groups comprise of the Ibans, 19 percent Malays, 8 percent Bidayuhs, 6 percent Melanaus and 7 percent comprising of other ethnic groups (Madeline, 2004; Dimbab, 2006). Nearly a majority of these Bumiputera ethnic groups work in the primary sector (43.4 percent) including activities such as hunting, collecting forest products, fish breeding and farming (Sarawak, 2007). Out of this percentage, 32.8 percent of the population are involved in agricultural activities (Sarawak, 2007) and the remaining works in the secondary and tertiary sectors (Sarawak, 2007). The percentage working in the tertiary sector is bigger because of the increased interest in the tourism industry and tourism related industry in Sarawak (Novel, et al. 2013). A total of 25 percent of Sarawak's population are urban based. Meanwhile, the remaining 75 percent are scattered in the rural areas and the pattern of the settlement distribution is generally closely linked to the type or form 
of employment or industry they are engaged in (Novel, et al. 2013; Madeline, 2004). Nearly a majority of the population that lives in the rural area comprise of Bumiputera ethnic groups (Sarawak, 2007).

In terms of the population distribution, most of the Bumiputera ethnic groups especially the Bidayuhs are involved in the main agricultural sector such as rubber, palm oil and paddy. At the same time, cattle farming has been given attention by the Bidayuh community especially for the palm oil smallholders as a result of the assistance given through Small Farmers Assistance Scheme (Skim Bantuan Penternak Kecil) and Scheme for the Development of the People's Well-being (Skim Pembangunan Kesejahteraan Rakyat) contained in the Ninth Malaysia Plan, 2006-2010 (Sarawak, 2006). From the year 2008-2010, more than 20 rural Bidayuhs were selected to be involved in beef cattle farming. However, this assistance did not involve assistance in the marketing of the cattle farming produce (Shukor, 2003; Fatimah, 2002). This situation led to great importance of social network in marketing of livestock for the cattle farmers, particularly in the condition of uncertain economic situation, increased competition, rising costs of livestock, livestock not well known, and the existence of uncertainty in the price of beef in the market (Shukor, 2003). Therefore, the main focus of this research was to examine the types of social network employed in the marketing of their cattle produce. The types of social network used subsequently will help them to remain involved in the sector of beef cattle farming.

\section{Research Methodology}

\subsection{Description of Study Area}

Serian district is located under the jurisdiction of Samarahan Division and is administered by a Resident after Samarahan was officially made a Division on 1st January 1987 (Sarawak, 2004). Each district is administered by a District Officer while the Sub-district is administered by an Administrative Officer (Sarawak, 2009; Sarawak, 2010). The district of Serian is actually one of the four districts in Samarahan Division, Sarawak (Sarawak, 2007; Sarawak 2008; Sarawak 2010) (please refer to Figure 2). In terms of the early history of Serian District's establishment, the district was formed in 1901 and was known as Sadong District. In February of 1955, it was known as Serian (Upper Sadong) after Simunjan (Lower Sadong) was separated and both were respectively upgraded to become a full district. Serian District covers an area of about 2,106 kilometre square and is located about 64 kilometres south of Kuching City or an hour's ride from Kuching City; it has a sub-district, namely the Sub-District of Tebedu which is the main International Border Crossing for Malaysia/Indonesia (in Sarawak) (Sarawak, 2004). This sub-district of Tebedu is located 43 kilometres from Serian City. In general, Serian District is bordered with Kuching Division in the north, Daerah Simunjan in the east and West Kalimantan, Indonesia in the south. Serian District has one main city and seven small towns which are the business centres for the people of this district (Sarawak, 2007). The main city is known as Serian City and it is one of the cities in Sarawak that was chosen in the Program Bandar Sejahtera since 2001 (Novel, et al. 2011).

\section{Research Method}

This study subsequently employed nine steps and principles in the effort to produce the characteristics of social reality and to develop categories and themes that would be able to form the basis of understanding or explanation of the problems to be analysed or examined (Blaikie, 2007). The steps and principles are as follows: 1 ) entering the social world and having the sensitivity toward several key themes as guide but the themes should act "non-directively"; 2) identifying the themes and categories used in the discussion on the topics to be investigated especially for themes and categories that are often repeated and frequently emerge in the conversations; 3) explaining the meaning of the themes and categories. These activities were continuous throughout the field study; 4) refining and narrowing the problem; 5) becoming part of the member of the Bidayuh community's social world by continually participating in their life and activities; 6 ) recording all comments and behaviour related to the main themes or categories; 7 ) themes or categories that have been identified to exist in the Bidayuh people about social network were tested again with other Bidayuhs; 8) finding relevant literature to gain ideas on how the themes and categories of the Bidayuh people about social network were used in their daily life. Activities on searching and reading of related literature were continuous until the themes or categories about social network of the Bidayuh community have been proven or strengthened; and finally 9) the themes or categories developed by the researcher should be presented again to the Bidayuh people for the purpose of member check to maintain the authenticity and truth of the scientific constructs as well as to increase the degree of validity and reliability of the concepts and categories. 


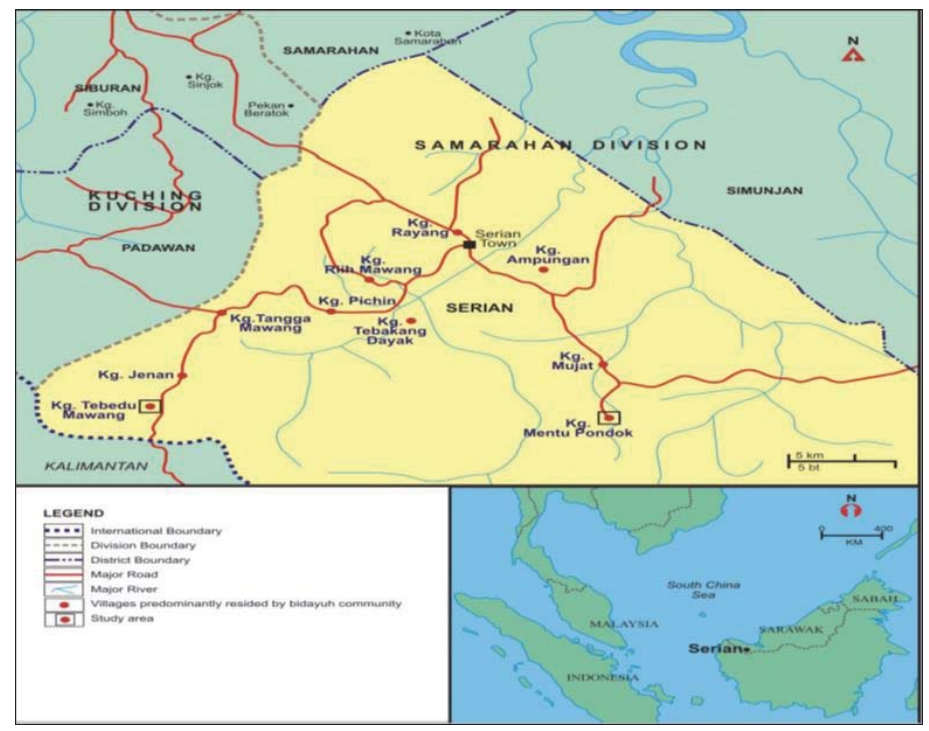

Figure 2: Study Location

The primary data were obtained from individuals and groups in natural social environment and also in semi-natural social environment. Natural social environment refers to the micro-social phenomena level of analysis (Blaikie, 2007; Burgess, 1984), in which in this level, information about the respondents was obtained by the researcher through the respondent's own experience of their daily life. In this study, data were collected using in-depth interviews for a period of four months. The in-depth interviews in this study involved conversation between two parties, namely between the researcher and respondents with one specific purpose which was to understand the types of social network used. Interviews between the researcher and the informants focused on the types of social network and the importance of social network in marketing of livestock products. Most of the interviews carried out took between two to three hours; however, some of the interviews took quite a long time. The research data was collected using non-probability sampling method which was purposive sampling and snowball sampling. A total of 9 rural cattle farmers who are very successful were interviewed in-depth. This study's sample size was achieved through continuous support of measurement or criteria on theoretical saturation. According to Glaser and Strauss (1967) and Lincoln and Guba (1985), theoretical saturation occurs or happens when there are no more new themes or categories that emerge and there are no more relevant data that could be discussed or act on the categories that exist. All the interviews was transcribed and formatted to be entered into the Nvivo database and will be used to create categories and to index the data. Nvivo is software that has been specially created or designed to help in storing and managing the whole analysis of the research's qualitative data. As the data were in the form of transcripts, hence the method employed was more geared to the formation of categories, making indexes or coding of documents, sorting data to identify patterns, explaining patterns and developing themes.

\section{Results and Discussion}

The researcher's discussion with the Bidayuh people who rear cattle in the rural areas began by asking the question "How do you find customers, what are the types of social network used to market the livestock?" The followings are the social network described by the respondents as the network that has a huge influence in the marketing of their livestock products. All seven types of network consist of network of family ties, friends, and friends of friends, radio, advertisements, language and wholesalers. From the seven types of social network, only three main types of social network were used often by the informants in marketing their agricultural products which are network of family, friends and friends of friends (please refer to Figure 3). The use of the three types of social network is consistent with the views expressed by Gu et al. (2008) and Dunning et al. (2007) who stated that social network of individual nature such as close family members, friends and friendship are the popular choices used by rural farmers in marketing their agricultural and livestock products. This is because the use of these social networks is viewed as easier, simpler and does not require 
high costs. Similar statement has been expressed by scholars such as Brown (1996) and Chou et al. (2006) who stated that the social network in rural areas is characteristically more individual and at the micro-level where their network is more to the feeling of belonging or kindred spirit such as family relationship, friendship, kinship, relatives, neighbours and friends. This situation happens because of their attitude that emphasizes aspects such as honesty, spirit of solidarity (esprit de corps), transparency and understanding in carrying out marketing of their livestock products (Shukor, 2003; Hwang et al. 2009; Chou et al. 2006). They very rarely use religious associations, clubs or organizations in looking for market for their livestock products because of the high costs, lack of knowledge, difficulty in trusting new media, the huge amount of time required and the need for high commitment and understanding between both parties (Fatimah, 2002; Shukor, 2003; Fang and Norman, 2006).

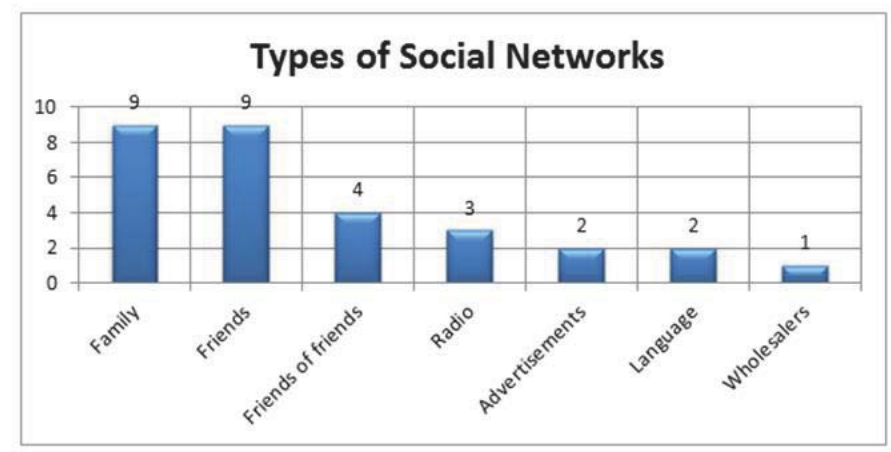

Figure 3: Types of social network according to main ranking

\subsection{Family social network}

Family social network in this study involved three types of family members, namely wife, children and close family members. These three types of family members will then look for their own customers. Therefore, it is not surprising when the majority of the informants in this study mentioned that without their wife, children and close family members, marketing of their cattle would not have been smooth, and that indeed it would be difficult to find customers. This is evident when on average informants such as $11,12,13,14,15,16,17$, 18 and 19 mentioned that their immediate family and close relatives were the ones who helped them a great deal in marketing their livestock products. For instance, II in his statement mentioned that the informant's own younger brother is the person who really helped in marketing the livestock particularly in finding customers outside of Serian district. The following is his statement about the matter: "In marketing the cattle livestock, family members helped a lot. They helped me to promote my cattle everywhere. For example, my younger brother who lives in Merau Village went to Bau which is a district outside of Serian district. He is the one who promoted my cattle to the people there. Thus, when there is a feast, usually they will make reservation through my brother". For I2, he said that his children are the ones who help him in selling his cattle: "I would not deny it that in selling my cattle, my children are the ones who help a lot. They will promote the cattle at their workplace especially to the ethnic Malays. 


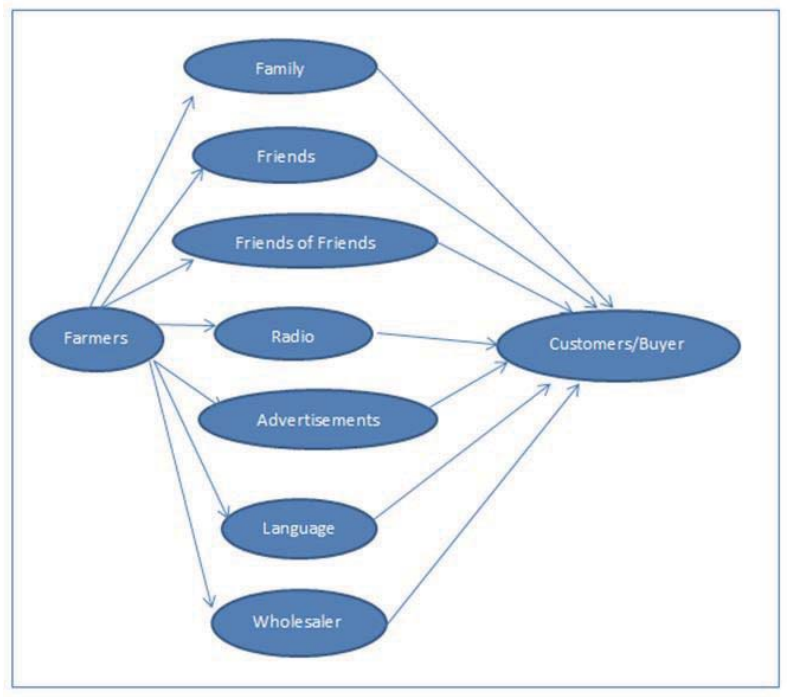

Figure 4: Types of social network of cattle farmers in marketing their produce

Their promotion is usually three months before the Muslims celebrate their Eid-ul-Fitr and Eid-ul-Adha". This is in contrast to 18 where his relatives, namely his own cousin who really helps him in selling his cattle products. This matter, according to him, is why his customers are mainly from among his cousin's workmates: "customers of my cattle are mostly the workmates of my own cousin who works at the Betong Division Police Station. This is because my cousin is the one who promotes my cattle. My cousin is the one who helps me a great deal in promoting my cattle". For 19, his children are the ones who greatly promote his livestock: "I am thankful that my children help me a great deal in selling my cattle products. The majority of my children work as teachers. They will promote the cattle to their work colleagues especially when it is nearing to Eid-ul-Adha and also for wedding feasts". In contrast, 14 and 17 mentioned that in marketing their cattle products, their in-laws or their wives' family are the ones who help them greatly in marketing their cattle. According to Informant 4, in marketing his cattle, his brother in-law helps a lot: "the family of my wife helps me greatly in selling my cattle. My brother in-law works as a teacher in SK Serembang. It is my brother in-law who promotes my cattle". The same statement was given by Informant 7 where his wife's siblings are the ones who help to promote his cattle: "my wife's family helps me a great deal in selling the cattle. My wife's siblings all work and they work in different places. They will promote my cattle to their work colleagues".

\subsection{Friends}

Majority of the informants in this study chose their friends as their main social network in finding customers. This is mentioned by all nine informants in this study. According to them, their friends greatly helped them in finding customers outside of Serian District. Their friends will help to spread the information about the location of the cattle, the type of cattle breed sold and the price of cattle sold to the public. These friends will then be given token payment for the help provided based on the number of cattle that could be sold through this network. The followings are some of the statements from selected informants on this matter:

"Apart from that, friends also help to sell my cattle. They will make known my name to whoever that needs cattle especially during the festive period". (19)

"My cattle are rarely promoted. This is because my friends help me greatly in selling the cattle". (I2)

"Usually, during festive season, many people come to buy cattle. According to my customers, they know that I sell cattle through my friends". (I7)

"I will not deny it that my friends help me a lot in telling the villagers as well as other villagers that I sell cattle. To a certain extent it helped me in selling my cattle products". (I3) 


\title{
5.3 Friends of Friends
}

A total of four informants chose this type of network in marketing their cattle livestock. Subsequently, friends of friends according to the informants of this study refer to the social interaction or communication that involves informants' friends with their friends. For example, one of the informants, namely 16 in this study mentioned that "friends of friends helped him a great deal in marketing his cattle livestock. This is because typically when they are good friends, he/she will introduce his/her cattle to their friends and their friends will introduce his or her friends to another friend as well. This situation normally happens two months before the festive season. This kind of thing makes me able to survive in cattle rearing until today". A similar tone was expressed by several other informants. Among them are 13,14 and 19. The followings are a few of the informants' statements about the matter:

\begin{abstract}
"With the large number of farmers and the intense competition, help from friends of friends assists me a great deal to remain competitive in cattle farming in the rural area". (I3)

"With road condition that is not quite good and the location of the cattle farms that are quite far from town, sometimes help from friends of friends really help in determining the success of a cattle farmer. This is what happened in my 10 years of experience of cattle rearing". (14)

"I am really thankful to the friends of my friends because they have introduced my cattle to the public. I am successful in the cattle farming sector because of the help and assistance of friends of my good friends". (19)
\end{abstract}

\subsection{Social Network in the Form of Radio}

Only a small number of informants mentioned that they use the radio in marketing their cattle. Usually the radio station that is the focus is the local radio stations, namely local radio stations using Sarawak Malay, Bidayuh and Iban language. This is acknowledged by three informants, namely 17, 18 and 19. The followings are several statements of the three informants on the matter:
"I often use the radio as a medium to market my cattle. I choose to promote my cattle business through radio announcements through YFM under Radio Televisyen Malaysia (RTM) Kuching". (I7)
"I have a relative who works as a radio deejay. I took the opportunity to ask for my relative's help to promote my cattle business". (18)
"Bidayuh and Iban radio station helped me greatly in promoting my cattle to the customers out there". (I9)

\subsection{Social Network in the Form of Advertisements}

Only two informants used advertisements as their social network. On average, informants rarely used this type of social network because the time and energy spent is quite a lot and it is tiring. This is because the type of advertisement used is characteristically traditional that is by pasting advertisements about the cattle at bus stations, village intersections, churches and public halls. The followings are the statements of the two informants:

"I use the traditional method in promoting my livestock. I will paste advertisements in churches, mosques, village intersections and places where there are a lot of people. To me, advertisements too, to a certain extent could help me in marketing my cattle products. Nevertheless, this method is a bit tiring and the outcome is difficult to predict since a lot of my advertisements have been removed by people". (I2)

"To promote the cattle, I also paste advertisements in surau, stalls, and in other village areas. Even though it is quite exhausting and I run the risk of the advertisements being torn or removed, I still have to do it. If not, it is difficult to find customers". (15)

\subsection{Type of Language}

Only two informants used this type of network in marketing their livestock. For them, language that is easily understood and has a lot of speakers facilitates them in marketing their livestock products. The two informants mentioned that they speak in Bidayuh, Iban and Sarawak Malay language to market their livestock. Their fluency in mastering the two languages helps them greatly in convincing their customers to buy their cattle products especially for customers of Malay and Dayak ethnicity. The feeling of belonging and clanship as well as state-ship exists when using the languages and this facilitates the business dealings between the two parties. For example, one informant, namely 14 felt that conversing in the same dialect will make them feel friendlier and easier to communicate. Subsequently 17 in his statement mentioned 
that "I like to speak in Iban, Bidayuh and Sarawak Malay language in marketing my livestock. These languages for me are the language of business. This is because since birth, I have conversed in Cantonese with my family and most of my friends. I feel friendly and there exists this sense of belonging during conversation. The use of these three languages helps in making it easier for me to find customers and subsequently facilitates in the marketing of the livestock products outside of Serian District".

\subsection{Wholesalers}

Only one informant in this study use wholesalers or middlemen as their type of social network. The use of wholesalers or middlemen had to be employed as the competition from other farmers was quite intense. Nevertheless, the use of wholesalers in marketing livestock products is limited and only employed when it is the harvesting or paddy planting season. The following is the statement of 16 on the matter:

"typically, I use middlemen when it is the paddy planting or harvesting season. This is because during that time, the time available is short and my physical condition that is quite exhausted because a lot of focus is given to the aspects of paddy planting and harvesting process. The wholesalers that I choose are the ones that can buy my livestock in quite large quantities, at least three or more".

\section{Conclusions}

In this study, family and friend social network are the primary type of social network employed by the cattle farmers. This situation clearly shows that 'sense of belonging' still remains as the main aspect in finding market. This corresponds to the comment expressed by scholars such as Aristotle who described man as 'social animals' who place emphasis on interpersonal relationship and cordial relationship (Fang and Norman, 2006; Frey and Stutzer, 2002). For them, having colleagues, close friends, family and relatives will contribute to the market. Accordingly, it is something that is not surprising when the two types of family and friend network are characteristically individual and of a small scale where the individual fully utilizes the available strength and influence in their social environment in looking for market either in the surrounding areas of Serian District or outside of Serian District. The use of social network that is of small scale and characteristically individual has resulted in the cattle market of the farmers in this study being quite limited and dependent on the extent to which the two types of network are cooperating and functioning competently, honestly and efficiently to achieve the goal. Cooperation here means a process in which two or more individuals who work together toward crossing a common goal as a result of the sharing of information, knowledge and learning. This intersection of the same common goal will subsequently create a consensus to cooperate with each other either in the business dealings or marketing.

\section{Acknowledgements}

The researcher would like to thank Universiti Kebangsaan Malaysia for the provision of the University-Community Incentive Grant (Project Code: KOMUNITI-2012-018) and Research University Grant (Project Code: GUP-2014-074) which enables smooth implementations of this research.

\section{References}

Abdul, R. A. (1990). The responses of farmers in two Bidayuh communities to an in situ land development programme. In King, V.T. dan Parnwell, J.G.(eds.), Margins and minorities: the peripheral areas and peoples of Malaysia. Hull University Press.

Blaikie, N. (2007). Social research. Paper presented at the Social Researching Workshop,11-13

December 2007 organised by School of Social Sciences, Universiti Sains Malaysia, Penang at Equatorial Hotel, Penang, Malaysia.

Brown, R.A. (1996). Chinese Business Enterprise Critical Perspective on Business and management. London, Routledge.

Burgess, R.G. (1984). In the field: an introduction to field research. London: Allen and Unwin.

Chou, L.F, Cheng, B.S, Huang, M.P. and Cheng, H.Y. (2006). Guanxi network and members' effectiveness in Chinese work teams: mediating effect of trust network. Asian Journal of Social Psychology, 9: 79-95.

Dimbab, N. (2006). Self-empowerment among oil palm smallholders in Miri Division, Sarawak.

Paper presented at the 8th Borneo Research Council International Conference, 31 July-1 August, at Holiday Inn, Kuching Sarawak.

Dunning, J.H. and Kim, C. (2007). The cultural roots of guanxi: An exploratory study". The world Economy, 85:1467-1475.

Fang, H. M. and Norman, P. (2006). Government mandated Discriminatory Policies and Evidence. International Economic Review, 47:221.

Fatimah, M.A. (2002). Pemasaran pertanian keperluan agenda pembaharuan (In Malay). Available from: http://psasir.upm.edu.my/ 
1111/1LG_173_S45_S981_no.50.

Frey, B.S. and Stutzer A. (2002). Happiness and economics. How the economy and institutions affect well-being. Princeton University Press, Princeton and Oxford.

Glaser, B.G. and Strauss, A.L. (1967). The discovery of grounded theory. Chicago: Aldine.

Grijpstra, B.G. (1976). Common efforts in the development of rural Malaysia. Studies of the development countries. Development Studies, 20: 142-157.

Gu, F.F., Hung K. and Tse. D.K. (2008). When does guanxi matter? Issues of capitalization and its dark side. Journal of marketing, 72 : $12-28$.

Hwang, D.B., Golemon, P.L., Chen, Y., Wang, T., S. and Hung, W. S. (2009). Guanxi and business ethics in confusion society today: an emprocal case study in Taiwan. Journal of Business Ethics, October 2009, 89 (2): 235-250.

Lincoln, Y.S. and Guba, E.G. (1985). Naturalistic inquiry. Thousand Oaks, CA: Sage.

Madeline, B. (2004). Towards the National Vision Policy: Review of the Economic Policy and New Development Policy among the Bumiputera Communities in Sarawak. Journal of Malaysia Studies, vI.XXI, No.1\&2.

Novel, et al. (2011). Intangible factors influencing gender differences in educational attainment using an abductive research strategy. World Applied Sciences Journal, 13, 46-52.

Novel et al. (2013). The world-view of Penan community on quality of life. Asian Social Science Journal, vol 9 (14): 98-105.

Ridu, J.R. (1994). Social and cultural change: trends among the Dayaks in Sarawak. Sarawak Museum Journal, 47: 137-143.

Sarawak. (1995). Department of Statistics. Population and housing census of Malaysia, 1995. Kuala Lumpur: Gov't Printing Office.

Sarawak. (2004). Department of Statistics. Population and housing census of Malaysia, 2004. Kuala Lumpur: Gov't Printing Office.

Sarawak. (2007). Department of Statistics. Population and housing census of Malaysia, 2007. Kuala Lumpur: Gov't Printing Office.

Sarawak. (2008). Department of Statistics. Population and housing census of Malaysia, 2008. Kuala Lumpur: Gov't Printing Office.

Sarawak. (2009). Department of Statistics. Population and housing census of Malaysia, 2009. Kuala Lumpur: Gov't Printing Office.

Sarawak. (2010). Department of Statistics. Population and housing census of Malaysia, 2010. Kuala Lumpur: Gov't Printing Office.

Shukor, O. (2003). The Malay Lost World with Emphasis in Entrepreneurship. Shah Alam, Anzagain Sdn Bhd, Kuala Lumpur, Malaysia.

Snijders, T.A.B., Van de Bunt, G.G. and Steglich, C.E.G. (2010). Introduction to stochastic actor-based models for network dynamics. Social Network, 32 (1): 44-60 